\title{
Persuasive Communication Media in The Implementation of the National Ideology
}

\author{
Irwan Tarmawan \\ Program Studi Desain Komunikasi Visual \\ Universitas Komputer Indonesia \\ Bandung, Indonesia
}

\author{
Wantoro \\ Program Studi Desain Komunikasi Visual \\ Universitas Komputer Indonesia \\ Bandung, Indonesia
}

\begin{abstract}
Pancasila, 1945 Constitution, NKRI, and Bhinneka Tunggal Ika, are consensus that are used as the basic pillars to be implemented from each of their values. The realization of the philosophy of the Indonesian nation as a guideline of life in everyday life, community, nation and state, absolutely must be carried out sustainability from generation to generation and across generations to complement each other upholding the philosophy that was built by its predecessors. Various parties with diverse interests carry out actions to restore the strength of this nation. Various stakeholders including the government through various program activities try to provide, strengthen, and increase nationality through national pillars in order to implement the ideological values of the nation as a whole. This research was carried out using a descriptive qualitative method with a phenomenological approach, seeing how convincing communication was carried out in various media, especially social media, as well as responses and reactions from the public to persuasive communication about strengthening the national ideology. Persuasive communication carried out in the implementation of ideology through various forms of communication media that will build awareness and change behavior in implementing the National Ideology. Persuasive communication media in the implementation of national ideology is events that involve perception in communication. To understand these activities, a phenomenological approach is used. The phenomenological approach aims to interpret social action as meaningful and can reconstruct other meanings in persuasive communication.
\end{abstract}

Keywords: Media, Persuasive Communication, implementation, national ideology

\section{INTRODUCTION}

Indonesia is a country that continues to grow and has now entered the era of globalization in various sectors with all its dynamics taking place. The Indonesian nation faces various challenges to be able to make the nation excel in various fields. The basis of the power to make Indonesia move forward to overcome all obstacles is marked by the strength of its nation. The Indonesian people agreed and carried out the basis of Pancasila Ideology and the foundation of the 1945 Constitution of the Republic of Indonesia as a guideline that regulates state life, nationality and society. The concept of the Unitary State of the Republic of Indonesia signifies the diversity of religions, tribes, races, cultures and all the norms that apply in the life of the community which is reflected in Bhinneka Tunggal Ika.

Pancasila, 1945 Constitution, NKRI, and Bhinneka Tunggal Ika, are consensus that are used as the basic pillars to be implemented from each of their values. The realization of the philosophy of the Indonesian nation as a guideline of life in everyday life, community, nation and state, absolutely must be carried out sustainably from generation to generation and across generations to complement each other upholding the philosophy that was built by its predecessors.

Today, when the Indonesian nation experiences the complexity of living with all the exposure in the face of a growing current, many things to watch out for. The era of globalization makes it easy for foreign parties to intervene, break up, so that there is a prolonged conflict. Conflict does not only occur in problems between groups of people but the conflict of Religion, the view of belief in God Almighty. Splits occur, loss of mutual trust, respect, tolerance, to the loss of nationalism towards the nation and religious beliefs.

Conditions that are increasingly not conducive and the character of the nation is increasingly unclear, the pillars of the state are increasingly shaken, so the concerned parties who are interested in taking actions to restore the strength of this nation. Various stakeholders including the government through various program activities try to provide, strengthen, and increase nationality through national pillars in order to implement the ideological values of the nation as a whole. The practice of each guideline contained in the philosophy of the Indonesian nation is the goal to be achieved in order to establish unity and unity and the essential Unity of Diversity. The socialization of national values through persuasive communication media is currently not going well, it looks not optimal in utilizing technology and media that continues to grow at this time. This is an interesting thing to study related to the form of implementing the ideology of nationality through a medium of persuasive communication.

\section{METHOD}

To find out about persuasive communication media in relation to the implementation of national ideology, qualitative research will be conducted. The research method used is descriptive method, namely research conducted on large / small populations, but the data studied is sample data taken from the population [1]. Geographically, research will be conducted through the internet and social networks.

Persuasive communication media in the implementation of national ideology are events that involve perception in communication. To understand these activities, a phenomenological approach is used. Reference [2] stated tht the phenomenological approach aims to interpret our social 
actions and that of others as meaningful (interpreted) and can reconstruct the derivative of meaning (the meaning used next) from meaningful actions on individual intersubjective communication in the world of social life.

Research on persuasive communication media will explore media forms and experiences from the community regarding the implementation of national ideology. This is in accordance with the direction of phenomenological studies. According to Polkinghorne phenomenological studies describe the meaning of a life experience for some people about a concept or phenomenon [3]. People involved in dealing with a phenomenon explore the structure of awareness of human life experiences.

\section{RESULTS}

\section{A. Persuasive Communication}

Communication is carried out to give and receive messages delivered, ways of persuasion as an effort to convey communication messages to be understood. According to Aristotle, emotional persuasion can attract attention and influence the audience if the speaker is trustworthy and supported by the power to use arguments along with clear and clear facts support.

Persuasion is a complex communication process of individuals or groups in conveying messages verbally and or non-verbally in order to get responses from other individuals or groups [4]. Devito revealed that persuasive talks convey messages that are reinforcing, provide illustrations, and information to audiences. Persuasive communication by using facts emotionally motivates the delivery of messages to change attitudes and behaviors using various communication components related between communicators or persuaders, messages, channels or media, to communicants or persuades.

\section{Persuader.}

Persuaders are individuals or groups of message providers who must have a high ethos that can affect the attitudes, opinions, and behavior of their target audiences. Ethos is a self-esteem value from a combination of aspects of cognition, affection, and connotation. A persuader must have receptive, selective, digestive, assimilative and transitive attitudes.

\section{Order.}

Message is everything that is delivered both verbally and non verbally. The message must be understood by the persuader and persuade. Persuaders must be able to deliver messages effectively through various forms of direct delivery or using the media.

The message according to Onong Effendy, states that the message is: "a component in the communication process in the form of a blend of one's thoughts and feelings by using symbols, language or other symbols conveyed to others".

\section{Persuade.}

Individuals or groups of message recipients. The success of receiving messages will be determined by various factors, ways, forms, and communication media.

\section{Channels.}

Channels are needed to convey messages from the persuade to the persuade. Channels or media as intermediaries must be appropriate to produce the expected effect.

\section{Effects.}

Is a feedback reaction to the perception of sending and receiving messages. The effect of persuasive communication is a change of thought, attitude, or behavior that occurs on the message received by the persuader through the communication process.

\section{B. Persuasive Communication Media}

One important component or element in persuasive communication is the need for channels or media as a way of conveying information. Sadiman, et al stated that media is everything that is used as a channel for messages and sending messages to the recipient of the message, so that it can stimulate thoughts, concerns, feelings, and interests. Persuasive communication media is a channel for producing and conveying information.

Communication media has a variety in reaching its target audience. Media coverage and media frequency will determine the effectiveness of message delivery. Broadly distributed media makes mass media that can be consumed simultaneously in a time determined by a large audience. However, personal media are also needed that target directly to each individual with certain conditions and times of information that they can receive.

The development of technology and the shifting of the activities of the community made the increasingly diverse personal media that developed, even shifting the establishment of conventional mass media. The growth of the internet and social media that are increasingly being accessed makes a media that must be considered in the dissemination of messages.

\section{Implementation of Nationality Ideology}

Pancasila as the basis of the state, national ideology, view of life of the nation and the unifying nation. All of these. Pancasila is a reference for legislation, the direction of nation building, and a view of life that shapes the mindset of attitudes and behavior and unifying the nation.

State of the Republic of Indonesia with the ideology of nationality based on Pancasila as the basis for supporting the achievement of national goals. living a state life by maintaining ideology as strength, character and identity of the Nation. Maintaining is not an easy matter in a multicultural cultural diversity that can give perception to one another. maintaining Pancasila as an absolute ideology is always upheld in the order of life of the fast.

\section{Implementation of Nationality Ideology through}

Persuasive Communication Media

The realization of the values of Pancasila is not always going well, conflicts that can cause conflicts often occur and consequently can undermine the values and practice of ideology in life. Ideology implementation is often perceived 
as the love of Pancasila. In its realization it is clear that Pancasila contains broad meanings and values and follows the dynamics of state life.

In the midst of the increasingly crisis conditions on Ideology, a lot of efforts were made in upholding and practicing the values of Pancasila. Efforts are made through persuasive communication media on the internet and social networks. Individuals or groups make efforts to uphold Pancasila with various forms of messages delivered.

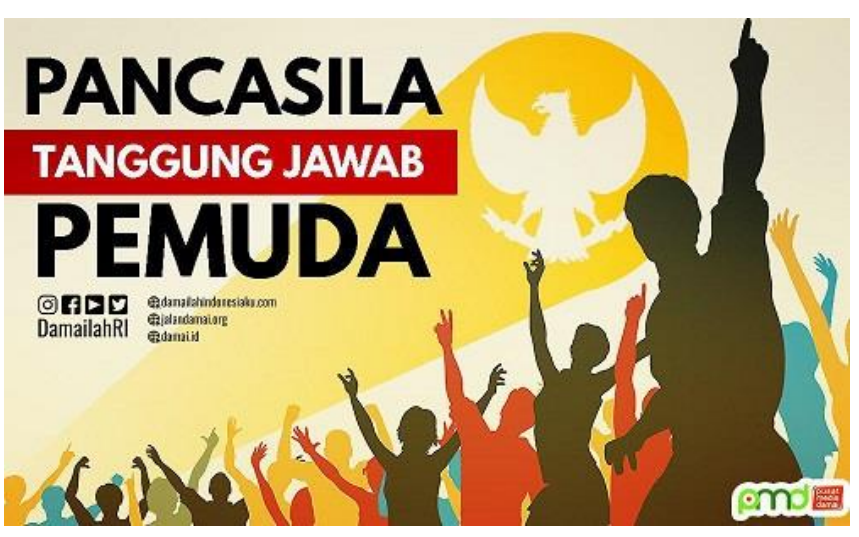

Fig. 2. One form of persuasive communication media from a website, as an opening on the homepage of a site

(Source: https://jalandamai.org/responsibility-pemuda-membumikanpancasila.html)

The message conveyed emphasizes Pancasila as a whole as a basis for its communication message. Emphasis on youth responsibility is an emotional form of attitude change that must be understood by the recipient of the message.

\section{DISCUSSION}

Persuasive Communication in Implementing National Ideology through internet media

Channels or media are very important in persuasive communication. The internet has now become a medium of information and communication. Website as an Internetconnected information page can contain any information, text, visual static or moving, and pemanfat a $\mathrm{n}$ audio.

The form of persuasive communication on the website is increasingly dominating. Communication is carried out based on the level of care and determination in maintaining the Pancasila ideology individually or in groups. Communication that emerges from the message of national ideology values becomes an assessment of the love and sense of nationalism towards the strengthening of ideology.

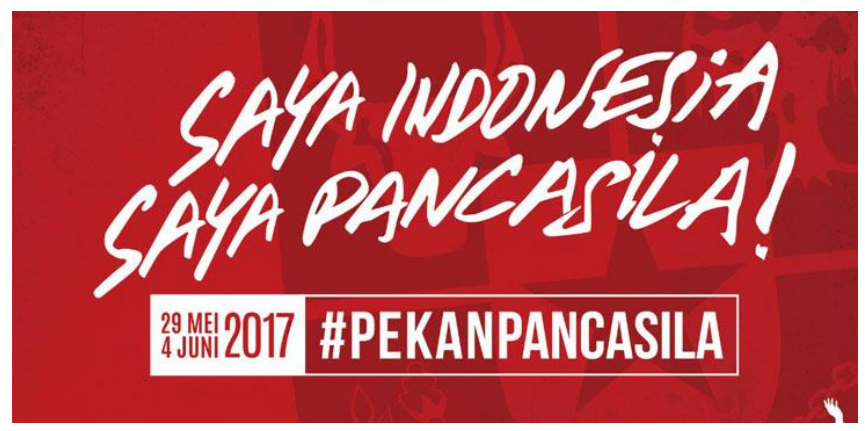

Fig. 3. One form of persuasive communication media from a website, part of the article page on the website

Persuasive Communication in Implementing National Ideology through internet media

Social networks are increasingly prevalent and so many users use social networks to communicate. Submission of messages from individuals dominates the delivery of persuasive communication.
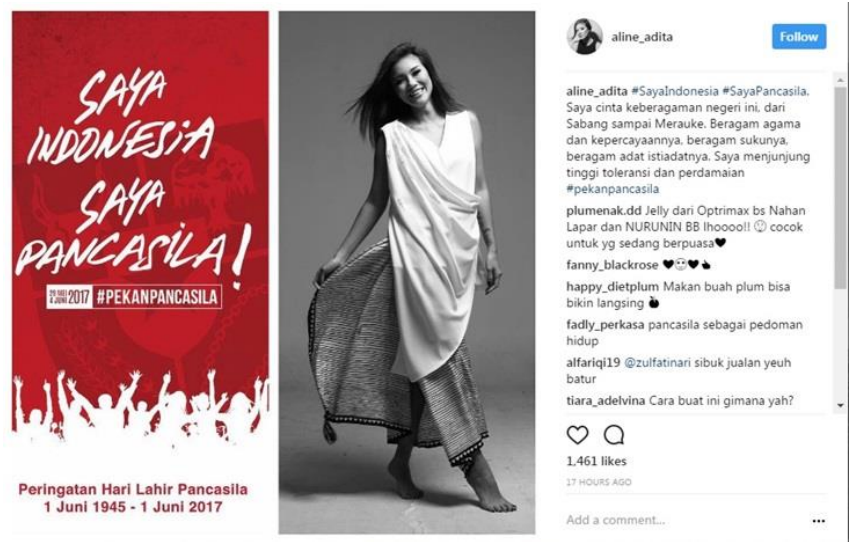

Fig. 4. Form of persuasive communication through Facebook social networks by creating a template so that individuals participate in being part of the Love of Pancasila

\section{CONCLUSION}

Persuasive Communication Media as a channel in the implementation of national ideology increasingly convey a ra sec individuals or groups. Submission of messages is often based on momentum. Whole awareness in maintaining ideology still depends on times related to the days that are considered appropriate to convey the message.

\section{ACKNOWLEDGMENT}

Thanks to Allah Subhanallahu Wataala, for all the abundance of mercy and guidance He has given confidence in completing this paper. Thank you to the Visual Communication Design Study Program for encouragement and access to ease in completing this paper. To the wife and children who are not tired of praying and being enthusiastic, and colleagues who have been part of the completion of this paper.

\section{REFERENCES}

[1] Sugiyono. (2010). Metode penelitian kuantitatif dan $r \& d$. Bandung, Indonesia: Alfabeta

[2] Creswell, John, W., Hanson, William, E., Clark, Vicki., \& Morale, Alejandro. (2007). Qualitative Research Designs: Selection and 
Implementation. The Counseling Psychologist, 35(2). Doi: 10.1177/0011000006287390.

[3] Creswell, John, W. (1998). Qualitative Inquiry and Research Design: Choosing Among Five Traditions. London, UK: Sage Publications.
[4] Littlejohn W. Stephen, Foss A. Karen, Oetzel G. John. 2017. Theorities of Human Communication, Waveland Press. United State of America. 